\title{
PENGGUNAAN TABLET DI BINUS ONLINE LEARNING
}

\author{
Agus Putranto; Wawan Saputra \\ Information Systems Department, School of Information Systems, Binus University \\ Jl. K.H. Syahdan No. 9, Palmerah, Jakarta Barat 11480 \\ aputra@binus.edu, wawans@binus.edu
}

\begin{abstract}
Utilization of e-learning can improve learning effectiveness and flexibility. Features of e-learning that are important in teaching and learning activities are tasks features, discussion forums and discussion face to face in a video conference. BINUS Online Learning is a program that offers students to conduct online lectures. Online BINUS need to think about software and hardware that must be provided in a tablet. Therefore, this study will analyze the use of the tablet which will be used for student BINUS Online Learning. The purpose of this study is to analyze the needs, and then determines the specifications of the tablet to be used as a replacement for netbook facility at Binus Online Learning. The research methodology used include, among others: Data Collection Methods (by conducting surveys), and the analysis method that consists of literature study and analysis of the system running, by using the rich picturer.
\end{abstract}

Keywords: tablet, application, hardware, e-learning, online, learning

\begin{abstract}
ABSTRAK
Pemanfaatan e-learning dapat meningkatkan efektivitas dan fleksibilitas belajar. Fitur e-learning yang penting dalam kegiatan belajar mengajar adalah fitur mengerjakan tugas, diskusi di forum diskusi dan diskusi tatap muka dalam video conference. BINUS Online Learning adalah suatu program yang menawarkan para mahasiswa untuk melakukan kegiatan perkuliahan secara online. BINUS Online perlu memikirkan perangkat lunak dan perangkat keras yang harus disediakan di dalam tablet. Oleh sebab itu, penelitian ini akan menganalisa penggunaan tablet yang akan digunakan untuk mahasiswa BINUS Online Learning. Tujuan penelitian ini adalah melakukan analisis kebutuhan, dan kemudian menentukan spesifikasi tablet yang akan digunakan sebagai pengganti fasilitas netbook pada BINUS Online Learning. Metodologi penelitian yang digunakan meliputi antara lain: Metode Pengumpulan Data (dengan melakukan survei), dan Metode Analisis yang terbagi atas studi kepustakaan, dan analisis sistem yang berjalan, dengan menggunakan rich picturer.
\end{abstract}

Kata kunci: Tablet, aplikasi, perangkat keras, e-learning, online, learning 


\section{PENDAHULUAN}

Pemakaian Teknologi Informasi sudah sangat luas dalam berbagai bidang industri di Indonesia. Internet dengan keunggulan dalam ruang dan waktu membuka peluang yang sangat besar untuk berkembang dalam dunia pendidikan. Saat ini banyak perguruan tinggi terus berinovasi untuk menjadi membuat sistem pembelajaran yang semakin mudah, cepat dan efektif. E-learning dapat menjadi salah salah satu cara yang diadopsi oleh banyak perguruan tinggi saat ini. E-learning adalah suatu metode pembelajaran dan pelatihan bagi mahasiswa yang memanfaatkan teknologi informasi untuk mengirim, mendukung, meningkatkan pembelajaran, dan melaporkan hasil pembelajaran.

Pemanfaatan e-learning dapat meningkatkan efektivitas dan fleksibilitas pembelajaran. Disamping itu materi dapat diperkaya melalui berbagai macam materi belajar termasuk multimedia yang interaktif untuk mendukung proses belajar mengajar. Dengan memanfaatkan e-learning, dosen dapat dengan mudah meng-upload materi kuliah, memberikan tugas untuk evaluasi, serta memonitor dan menjalin komunikasi dengan mahasiswa melalui teknologi berbasis web. Perkembangan teknologi mobile juga berkembang dengan sangat pesat dan perangkat mobile bisa didapat dengan harga yang murah. Perangkat mobile memungkinkan pengaksesan suatu informasi kapan dan di mana saja dengan menggunakan menggunakan perangkat mobile, seperti handphone, PDA, smartphone, atau yang sedang booming sekarang ini yaitu tablet PC.

Pemanfaatan internet untuk mendukung program belajar mengajar, sudah mulai dilaksanakan di lingkungan Binus University sejak tahun 1998. Sejak 2008 ini, Binus University mulai menawarkan program Online Learning bagi masyarakat yang memiliki kendala untuk mengikuti perkuliahan secara regular. Dengan menawarkan Fleksibilitas melalui metode belajar yang tidak terikat dengan tempat dan waktu namun tetap fokus sehingga menjamin kualitas lulusan program Online Learning ini akan sama dengan lulusan yang berkuliah secara regular. Online Learning menggunakan LMS (learning management system) yang terintegrasi untuk membangun jaringan interaksi antara mahasiswa dengan mahasiswa, mahasiswa dengan dosen dan mahasiswa dengan pembimbing akademis. Dengan demikian mahasiswa program online learning dipastikan mempunyai kualitas yang sama dengan mahasiswa yang melakukan sistem perkuliahan pada umumnya. Melalui pembelajaran melalui media online, maka pembelajaran dapat dilakukan tanpa ada batasan waktu dan tempat, sehingga mahasiswa online akan berasal dari berbagai daerah dan negara yang akan dipandu oleh dosen-dosen BINUS yang tidak hanya berada di Jakarta tetapi juga yang sedang berada di luar negeri. Forum diskusi sebagai media komunikasi antara para mahasiswa dan dosen juga sudah digunakan pada LMS (learning management system) BINUS Online Learning.

Sekarang ini mahasiswa mendapatkan netbook untuk perkuliahan online. Netbook mengisi kekosongan antara PC desktop dan laptop, tetapi belakangan ini muncul iPad dan tablet android dan mulai populer, banyak orang bahwa tablet akan menjadi alat yang menemani dibanding dengan laptop atau PC desktop. Dan akhir-akhir ini ada isu bahwa netbook akan tidak diproduksi lagi, oleh sebab itu netbook akan digantikan dengan tablet.

Masalah yang dihadapi adalah dalam mengerjakan tugas, mengakses forum diskusi, mengikuti video conference akan menggunakan perangkat keras dan piranti lunak tertentu. BINUS Online perlu memikirkan perangkat lunak dan perangkat keras yang harus disediakan di dalam tablet. Oleh sebab itu, penelitian ini akan menganalisa penggunaan tablet yang akan digunakan untuk mahasiswa BINUS Online Learning. Dengan penelitian ini diharapkan dapat membantu BINUS Online Learning dalam menentukkan tablet yang sesuai. Agar penelitian ini tidak melebar maka penulis memberikan tiga batasan. Pertama, penelitian menggunakan studi kasus pada BINUS Online Learning. Kedua, dalam menganalisa e-learning yang berjalan, penelitian akan menganalisa kemudahan dalam mengerjakan tugas, melakukan diskusi di forum diskusi dan pelaksanaan video conference. Dan terakhir, analisa perangkat keras dan piranti lunak ini hanya digunakan untuk para mahasiswa, bukan dosen. 
Tujuan dari penulisan ini yaitu melakukan analisis terhadap e-learning dari sistem yang sedang berjalan, dan menentukan spesifikasi tablet yang akan digunakan oleh mahasiswa BINUS Online Learning. Selain tujuan, manfaat dari penulisan ini adalah meningkatkan mobilitas mahasiswa melalui tablet, dan mempermudah interaksi dengan dosen, dan peningkatan waktu belajar dari mahasiswa BINUS Online Learning.

\section{Tinjauan Pustaka}

\section{E-Learning}

Menurut Ruth (2010), kita dapat mengetahui untung rugi dari penerapan e-learning, dimana penerapan e-learning bukan berarti akan menghemat biaya, namun membutuhkan biaya yang besar untuk implementasinya seperti biaya pengadaan jaringan, server, maupun infrastruktur teknologi yang lainnya. Selain itu belum tentu semua pihak dalam organisasi mendukung e-learning tersebut karena ada beberapa pihak yang takut pekerjaan dan kekuasaan mereka akan terancam dengan adanya $e$ learning ini.

Berdasarkan Tsai (2010), e-learning digunakan untuk dapat menyampaikan materi pelajaran atau pelatihan tanpa adanya batasan tempat dan waktu, yang pada akhirnya akan meningkatkan kualitas dari proses pelatihan tersebut. Untuk mencapai kualitas dari pelatihan juga dibutuhkan kolaborasi dari berbagai jenis $e$ - learning baik yang bersifat synchronous maupun asynchronous. ELearning mengacu pada semua kegiatan pelatihan yang menggunakan media elektronik atau teknologi informasi. (Effendi dan Zhuang, 2005).

\section{Kelebihan Mobile Learning}

Andy (2007) menjelaskan bahwa di luar keterbatasan yang dimiliki oleh m-learning, sistem ini memiliki beberapa kelebihan dibandingkan dengan sistem e-learning, yaitu: portabilitas, mendukung pembelajaran, meningkatkan motivasi, jangkauan lebih luas serta pembelajaran tepat waktu. Andy (2007) juga menjelaskan perbedaan yang paling besar antara e-learning dan m-learning adalah dalam hal karakterisktik hardware/software perangkat. Akses ke web melalui perangkat mobile, dengan ukuran layar kecilnya, telah menjadi masalah yang menarik bagi banyak peneliti.

\section{Tablet Computer}

Tablet PC menurut Gates (Microsoft, 2000) adalah kombinasi kemampuan dari seluruh fungsi personal komputer dengan kesederhanaan penggunaan pulpen, dan kertas.

\section{Discussion Forum}

Forum merupakan sebuah media berdiskusi dimana dibagi menjadi topik-topik diskusi yang berbeda (Watkins, 2006). Tidak ada forum untuk berdiskusi yang lebih baik dari forum diskusi. Dengan forum diskusi, murid dan pengajar dapat berdiskusi (Morris dan Stommel, 2013)

\section{Video Conference}

Video conference adalah teknologi teleomunikasi audio dan video secara sincronour, dimana orang dapat berbicara dengan yang lain dari dua atau lebih lokasi yang berbeda, selain itu dapat pula mengirimkan file, dan aplikasi (Rachel, 2009) 


\section{METODE}

\section{Analisis Sistem Berjalan}

Semua proses dilakukan melalui LMS Binus Online Learning via Internet. Untuk menggambarkan analisis sistem yang berjalan, penulis menggunakan rich picture untuk mempermudah pemahamannya.

\section{Rich Picture Sistem Berjalan E-Learning}

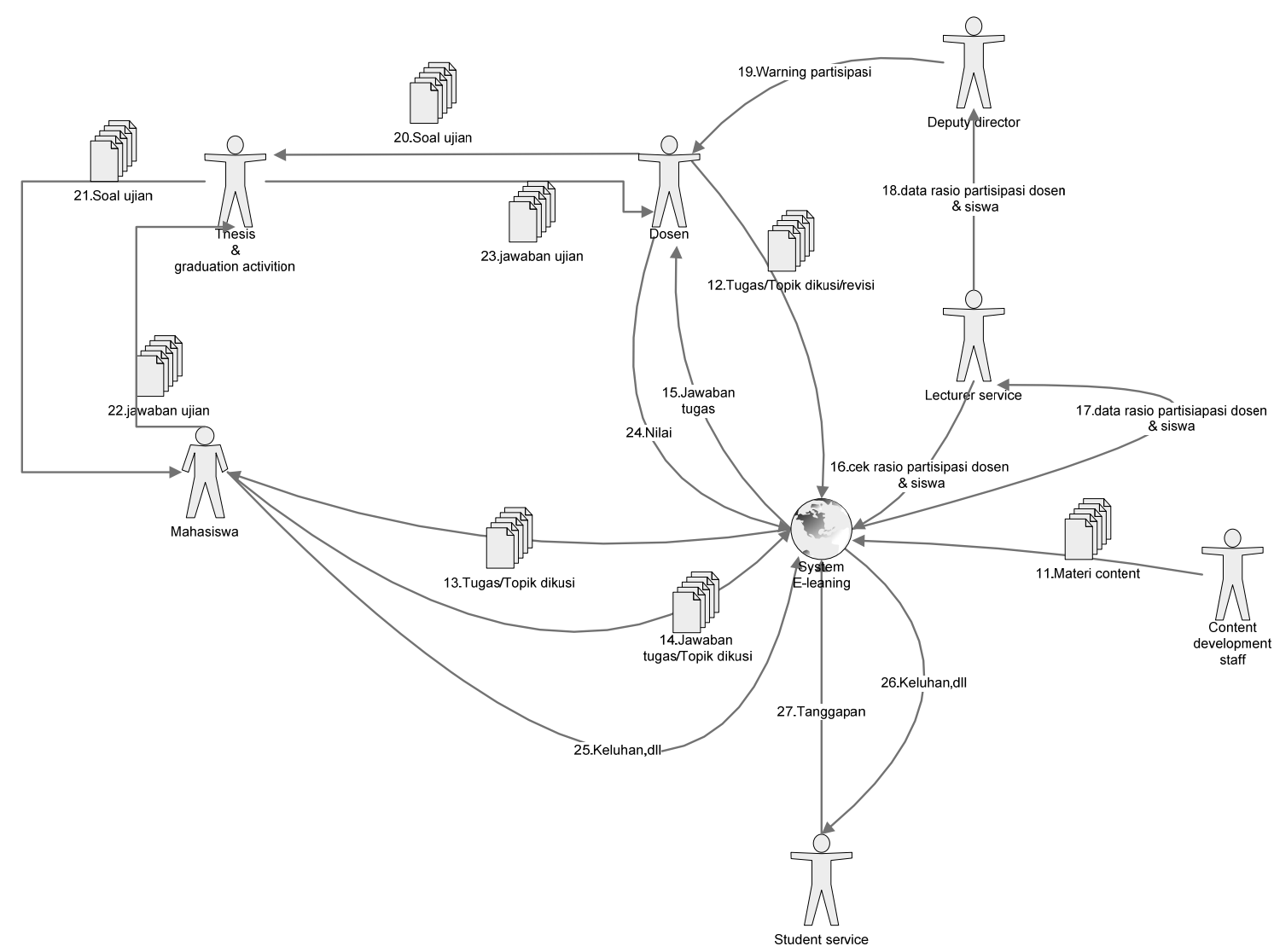

Gambar 1 Rich Picture Sistem Berjalan E-Learning

\section{Deskripsi Rich Picture Sistem Berjalan E-Learning}

Pertama, bagian Content Development Staff yang menggunakan komputer desktop melalui jaringan internet, meng-upload konten materi pembelajaran kedalam database LMS Binus Online Learning. Setelah itu dosen akan memberikan topik diskusi dan tugas untuk setiap pertemuan, (biasanya batas waktu satu pertemuan adalah satu minggu) ini pun melalui website Binus Online Learning. Kemudian jika ada tugas yang perlu direvisi, maka dosen akan menginformasikan kepada mahasiswa melalui Discussion Forum Class room. Topik diskusi dan tugas tersebut dapat diakses oleh mahasiswa melalui LMS dan Discussion Forum Class Room. Topik diskusi dan tugas tersebut nanti akan dikerjakan oleh mahasiswa dan mengumpulkan melalui LMS. Kemudian jika terjadi revisi, maka mahasiswa wajib untuk memperbaiki sesuai dengan batas waktu yang diberikan oleh dosen. 
Dalam Discussion Forum, dosen akan menanggapi jawaban topik diskusi yang diberikan oleh setiap mahasiswa, dan jika ada pertanyaan, maka dosen juga wajib untuk menanggapinya. Untuk tugas yang diberikan, maka dosen akan membuat penilaian. Untuk forum diskusi per mata kuliah di bagi menjadi empat forum (Class Room, Team Room, Meet The Lecture, dan Personal Room), sehingga mahasiswa bisa berdiskusi dengan cara memasuki salah satu forum. Class room, adalah tempat bertemu dan berinteraksi antara dosen dengan mahasiswa dalam satu kelas dan satu mata kuliah.

Dosen membuat topik pembahasan untuk ditanggapi oleh sesama mahasiswa. Mahasiswa juga dapat membuat topik pembahasan untuk ditanggapi oleh dosen atau oleh sesama mahasiswa. Sesama Mahasiswa memberikan tanggapan dan pembahasan topik yang telah diberikan oleh dosen dan sesama mahasiswa. Dosen juga memberikan tanggapan dari pertanyaan atau topik yang diberikan oleh mahasiswa. Dalam team room, satu mahasiswa memberikan tanggapan dan bahasan untuk anggota tim yang lain. Mahasiswa satu kelompok mengakses bahasan yang diberikan oleh teman sekelompoknya. Anggota tim yang lain memberikan tanggapan dari bahasan yang diberikan oleh teman kelompok sendiri.

Meet the lecture, adalah forum yang digunakan untuk bertemu dengan dosen secara personal. Mahasiswa memberikan pertanyaan yang sifatnya pribadi untuk dosen yang mau dihubunginya melalui Meet The Lecturer Forum. Dosen mengakses pertanyaan dari Meet The Lecturer Forum. Dosen memberikan tanggapan dan jawaban ke Mahasiswa dari pertanyaan mahasiswa dari Meet The Lecturer Forum. Sedangkan personal room, dosen tidak bisa ikut terlibat dalam forum ini. Mahasiswa memberikan tanggapan dan pembahasan topik antar mahasiswa dikelas itu sendiri. Mahasiswa mendapatkan tanggapan dan pembahasan topik antar mahasiswa dikelas itu sendiri. Mahasiswa dapat memberikan pula lampiran dalam bentuk file jika diperlukan. File dapat berupa dokumen ataupun powerpoint.

Bagian Lecturer Services \& Class Monitoring Staff bertugas untuk mengecek rasio partisipasi mahasiswa ataupun dosen sendiri, untuk mengetahui bahwa keaktifan kelas berjalan dengan baik. Bagian ini pula yang akan membuat sebuah laporan yang berisikan rasio keaktifan dosen yang mengajar di setiap kelas, dan laporan tersebut akan dibuat setiap bulannya, memberikan laporan keaktifan dosen dan mahasiswa tersebut kepada Deputy Director yang bertugas untuk memastikan bahwa kelas sudah berjalan dengan baik. Deputy Director akan memberikan peringatan atau teguran bagi dosen yang tidak aktif dalam kegiatan pembelajaran di kelas.

Mahasiswa mengerjakan tugas personal maupun tugas kelompok. Sebelum mengerjakan tugas mahasiswa mengambil file dalam bentuk dokumen ataupun powerpoint. Mahasiswa mengerjakan tugas menggunakan aplikasi office seperti Microsoft Office. Kemudian mengirimkan ke dosen melalui LMS pada menu Assignment. Dosen mengkoreksi dengan mengambil file yang dikirim mahasiswa.

Dosen akan memberikan soal ujian kepada Bagian Thesis \& Graduation Staff. Kemudian bagian Thesis \& Graduation Staff akan melakukan penjadwalan ujian yang akan dilakukan oleh mahasiswa dan melakukan ujian berdasarkan soal ujian yang diberikan oleh dosen mata kuliah. Mahasiswa akan datang ke Binus untuk mengikuti ujian, baik itu UTS maupun UAS dan mengerjakan soal ujian. Bagian Thesis \& Graduation Staff akan memberikan jawaban ujian yang dikerjakan oleh mahasiswa kepada desen yang mengajarnya. Setelah Dosen selesai melakukan penilaian terhadap hasil ujian mahasiswa, maka Dosen akan meng-upload nilai mahasiswa kedalam database melalui LMS.

Mahasiswa dapat mengadukan keluhan-keluhan mengenai kelas ataupun dosen dengan menuliskan keluhan tersebut melalui Public Forum, yang di mana forum ini berfungsi sebagai wadah untuk melakukan pertanyaan ataupun keluhan mengenai dunia pembelajaran di luar mata kuliah. Keluhan ataupun pertanyaan ini akan dapat diakses oleh Bagian Student Services \& Helpdesk Staff. Bagian Student Services \& Helpdesk Staff akan memberikan tanggapan terhadap keluhan dan pertanyaan yang diajukan oleh mahasiswa. 


\section{Platform Mobile}

Ada banyak platform yang bisa dipilih pengembang untuk membuat aplikasi. Masing-masing platform cenderung tidak kompatibel satu sama lain sehingga menyebabkan sebuah aplikasi yang dibuat di suatu platform tidak akan berjalan pada platform lain dan setiap perangkat mobile hanya mendukung satu platform. Oleh karena itu, agar aplikasi bisa mendapatkan hasil yang maksimal, seorang pengembang harus menentukan platform mana yang tepat bagi proyeknya.

Platform yang mendukung perangkat untuk berbagai manufaktur adalah Java ME; secara umum platform ini menghasilkan aplikasi yang portabel, meskipun kadang-kadang perangkat hardware spesifik membuatnya tidak portable. Symbian platform; didesain khusus untuk perangkat mobile, platform Symbian bersifat real-time, multi-tasking, dikhususkan agar berjalan baik pada resource sistem yang terbatas. Platform ini juga memaksimalkan unjuk kerja dan menghemat daya baterai dan meminimalkan penggunaan memori. Symbian Foundation mempertahankan kode untuk open source software platform berdasarkan Symbian OS dan software asset kontribusi Nokia, NTT, DOCOMO dan Sony Ericsson, termasuk antarmuka S60 dan MOAP(S). Platfrom ini sepenuhnya open source (sumber terbuka). Lebih dari tiga juta unit perangkat mobile berdasarkan Symbian OS telah terjual dan Symbian memegang pasar lebih dari 50\%.

Android; adalah platform berdasarkan Linux dari Open Handset Alliance, terdiri dari 34 anggota termasuk Google, HTC, Motorola, Qualcomm dan TMobile. Mendukung 34 perangkat lunak besar, perangkat keras, dan perusahaan telekomunikasi. Kernel Linux digunakan sebagai Hardware Abstraction Layer (HAL). Pemrograman aplikasinya menggunakan bahasa Java. NET Compact Framework; digunakan terutama untuk aplikasi pada Pocket PC/Windows Mobile, meskipun sekarang bisa digunakan pada perangkat Android. BREW; digunakan untuk aplikasi pada perangkat CDMA (tapi juga mendukung model GPRS/GSM). Didistribusikan melalui Brew Content Platform. Windows Mobile, Palm OSm, Flash Lite; digunakan untuk perangkat yang mendukung Flash LitePlayer, Microbrowser

\section{Survei}

Adapun perkembangan jumlah mahasiswa Binus Online Learning adalah sebagai berikut: tahun 2009 pada semester 1 sebanyak 43 orang, semester 2 sebanyak 57 orang, sedangkan tahun 2010 semester 1 sebanyak 70 orang, semester 2 sebanyak 143 orang. Di tahun 2011 semester 1 sebanyak 137 orang dan di semester 2 sebanyak 243 orang dengan jumlah mahasiswa aktif sekarang ini adalah sebanyak 670 orang. Survei dilakukan pada lebih dari $10 \%$ total mahasiswa Binus Online Learning yang ada. Survei diadakan pada saat perkuliahan onsite atau belajar di ruang kelas sebelum melakukan ujian pada pertemuan ke-10, sample yang diambil sebanyak 72 orang, dengan kelas yang diambil secara acak serta jurusan yang acak juga.

\section{Hasil Survey}

Pertanyaan pertama, mengenai sistem operasi handphone/tablet yang digunakan mahasiswa Binus Online Learning saat ini. Hasil ini untuk mengetahui platform handphone/tablet yang sedang digunakan sekarang ini. Saat ini Blackberry banyak digunakan, walau demikian, pertanyaan kedua yaitu tentang sistem operasi apa yang akan berkembang di masa depan. Sistem operasi handphone/tablet yang dianggap mahasiswa akan berkembang pesat dan banyak digunakan adalah sistem operasi android. Platforms yang akan diteliti lebih lanjut dalam hal ini adalah Android. 


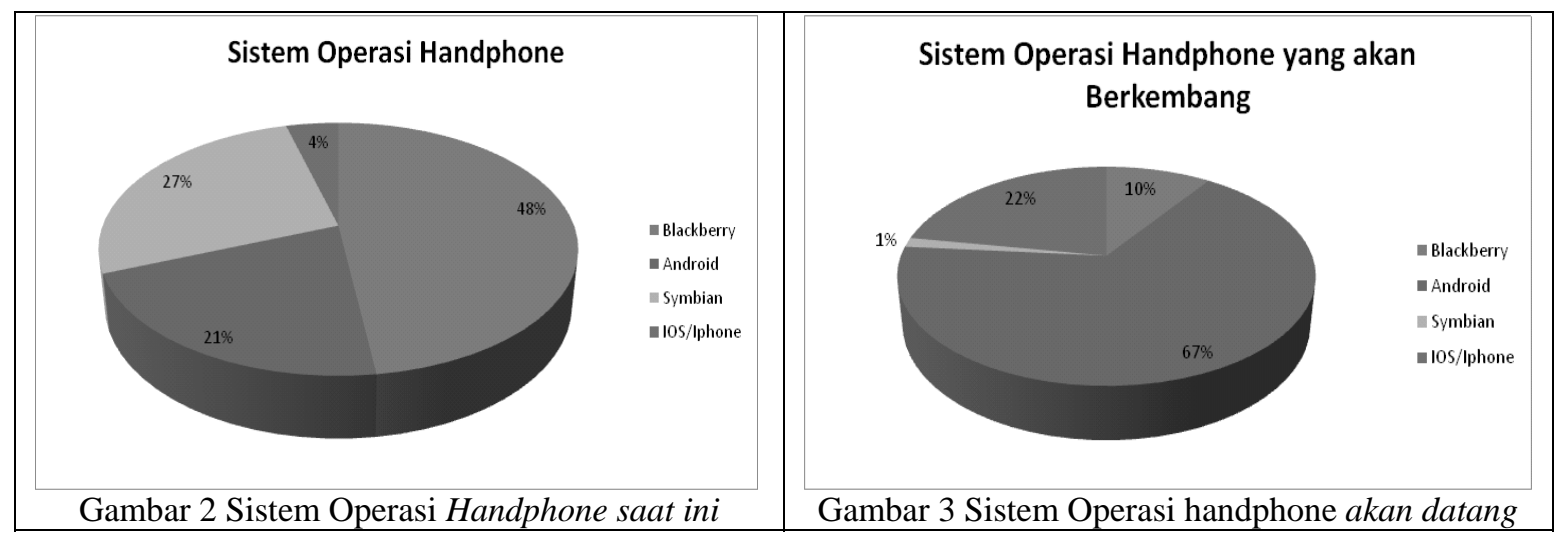

Pertanyaan ketiga, yaitu aplikasi yang dibutuhkan dalam mengerjakan tugas. Mayoritas responden menggunakan pengolah kata, sebanyak 64 orang atau 89\%. Menggunakan lembar kerja dan pengolah gambar sebanyak tiga orang atau $4 \%$. Multimedia, animasi sebanyak satu orang atau $2 \%$, sedangkan lain-lain sebanyak satu orang atau 1\% (Lihat gambar Aplikasi digunakan mengerjakan tugas).

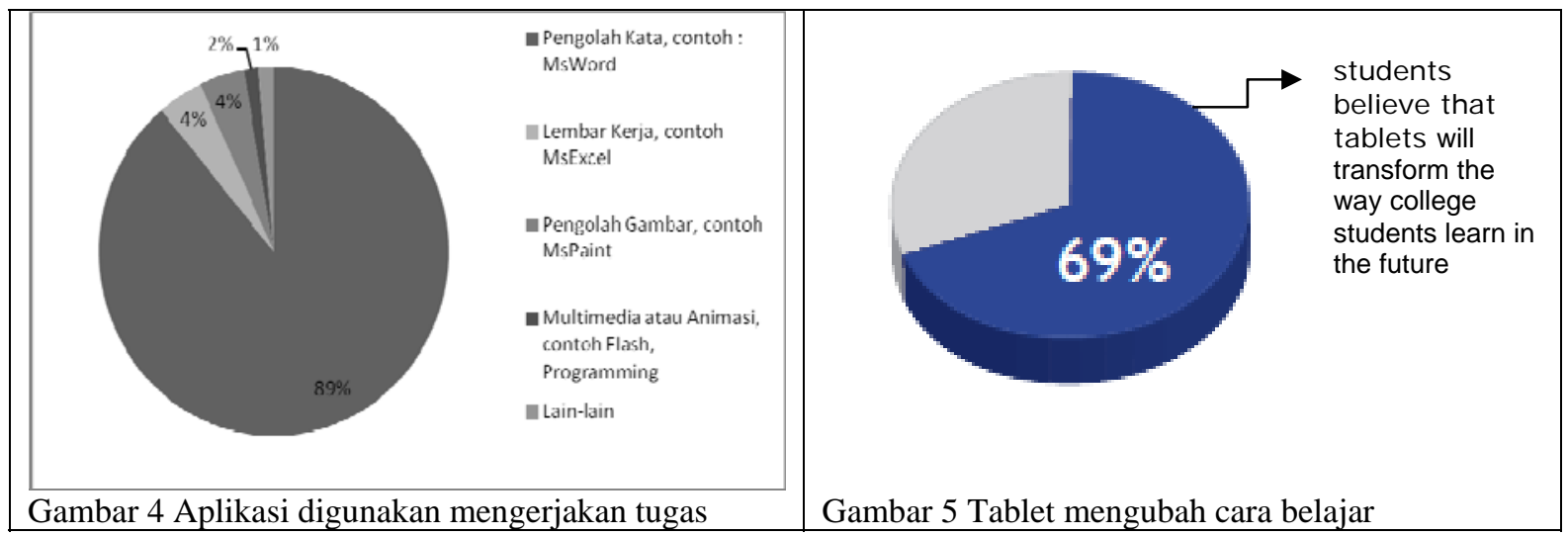

Murid-murid lebih menyukai menggambar dengan menggunakan tablet, dari pada menulis secara traditional (Cause, 2010). Pearson Foundation (2011) melakukan survei yang ditujukan kepada 1214 mahasiswa dan 200 lulusan sekolah menengah atas di Amerika Serikat yang berumur 18 sampai dengan 30 tahun, dan mendapatkan hasil 69\% mahasiswa percaya bahwa tablet akan mengubah cara mahasiswa belajar (Lihat gambar tablet mengubah cara belajar), 70\% menyatakan bahwa tablet membuat belajar lebih menyenangkan, 70\% ingin membeli tablet. 86\% mengatakan belajar dengan tablet membantu belajar lebih efisien.

Pertanyaan keempat, bertujuan untuk mengetahui penggunaan tablet oleh pemilik tablet. Pertanyaan yang diberikan adalah jika Anda pengguna tablet, apa yang sering Anda lakukan dengan tablet Anda: (beri tanda $v$ jika anda sering lakukan). Dan hasil yang didapat bahwa mayoritas pengguna tablet mengunakan untuk mengetik/membalas e-mail, diikuti membaca/mempelajari informasi, calendar management, membuat catatan, dan bermain game. 


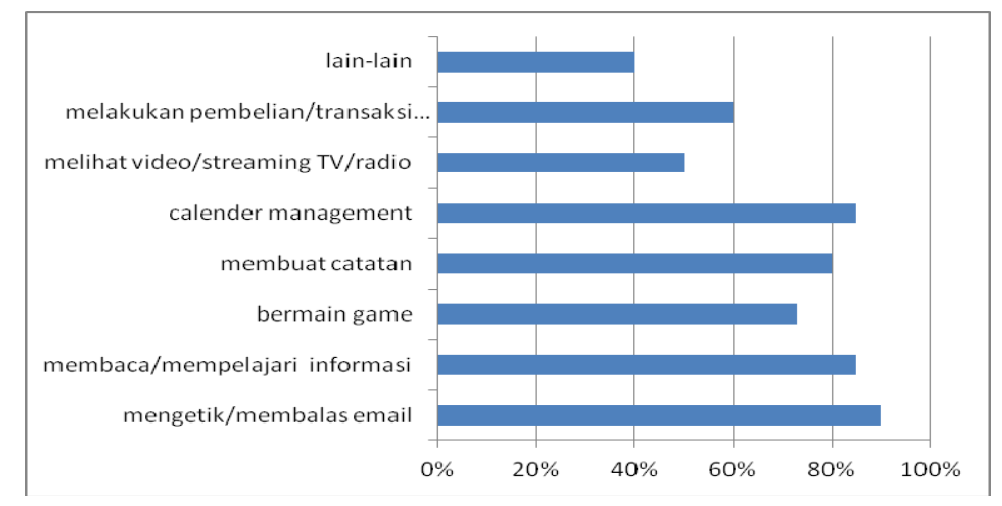

Gambar 6 Penggunaan tablet oleh pemilik tablet

Tahun 2013, setiap pekerja atau pengguna sudah memiliki perangkat mobile masing-masing seperti ponsel pintar, laptop atau tablet. Para pekerja tidak lagi membutuhkan komputer PC kantor untuk mengerjakan pekerjaan kantor karena cukup dengan tablet (Republika, 2012).

\section{HASIL DAN PEMBAHASAN}

\section{Kebutuhan Aplikasi}

\section{Aplikasi umum}

Aplikasi umum yang digunakan untuk mengakses Learning Management System adalah browser. Ada beberapa browser yang bisa digunakan antara lain: FireFox Mozila, Internet Explorer, atau Chrome Browser, UC Browser.

\section{Aplikasi khusus}

Berdasarkan rich picture system yang sedang berjalan, aplikasi khusus dilihat berdasarkan kegiatan yang dilakukan oleh mahasiswa BINUS Online Learning dalam proses belajar, aplikasi khusus yang akan didukung dapat dilihat pada tabel di bawah ini.

Tabel 1 Kebutuhan Aplikasi untuk Perkuliahan Online

\begin{tabular}{|c|c|c|}
\hline Kegiatan & Kebutuhan Aplikasi & Fungsi \\
\hline Forum Diskusi & $\begin{array}{ll}\text { - } & \text { File Explorer, } \\
\text { - } & \text { Document (office), } \\
\text { - } & \text { Screen Capture }\end{array}$ & $\begin{array}{ll}- & \text { Menampilkan file yang akan diupload } \\
\text { - } & \text { Membuat file dokumen dalam bentuk power point, } \\
\text { pengolah kata, lembar kerja yang perlu ditulis di file } \\
\text { terpisah }\end{array}$ \\
\hline Pengerjaan Tugas Personal dan & File Explorer & - $\quad$ Menampilkan file yang akan di-upload \\
\hline Tugas Kelompok & $\begin{array}{ll}\text { - } & \text { Document (office), } \\
\text { - } & \text { Screen Capture } \\
\text { - } & \text { Aplikasi lain }\end{array}$ & $\begin{array}{l}\text { - Membuat file dokumen dalam bentuk power point, } \\
\text { pengolah kata, lembar kerja yang perlu ditulis di file } \\
\text { terpisah } \\
\text { - } \quad \text { Menangkap gambar dan dikirimkan di forum diskusi } \\
\text { - }\end{array}$ \\
\hline Video Conference & $\begin{array}{ll}\text { - } & \text { Flash } \\
\text { - } & \text { File Explorer }\end{array}$ & $\begin{array}{ll}\text { - } & \text { Untuk menjalankan video dan audio } \\
\text { - } & \text { Untuk mencari file yang akan ditampilkan }\end{array}$ \\
\hline
\end{tabular}




\section{Forum Diskusi}

Proses dalam forum diskusi adalah mahasiswa menjawab pertanyaan dosen atau mahasiswa lain, menanggapi diskusi sebelumnya, menambahkan /mengambil gambar dan mengambil dari website. Forum diskusi sudah langsung ada dalam Learning Management System, sehingga hanya dibutuhkan browser saja. Tetapi ada pekerjaan yang membutuhkan aplikasi lain, seperti edit diskusi, dimana peserta perlu berpikir dan membutuhkan waktu yang cukup lama sehingga ada time out juga dalam Learning Management System. Untuk membantu dalam mengedit diskusi, dan membuat diskusi lebih mendalam, ada beberapa aplikasi pengolah kata yang dibutuhkan, antara lain OpenOffice, KingOffice atau lainnya. Sedangkan untuk menambahkan/mengambil gambar dapat menggunakan beberapa aplikasi antara lain: Screenshoot UX, Screen Capture.

\section{Pengerjaan Tugas Personal dan Tugas Kelompok}

Sebelum tugas dikerjakan, mahasiswa wajib men-download soal, baik soal untuk tugas perorangan maupun soal tugas kelompok. Soal dalam bentuk pengolah kata sebesar $90 \%$, dan dalam bentuk powerpoint sebesar $10 \%$. Tugas personal maupun tugas kelompok dikerjakan dan dikumpulkan menggunakan pengolah kata, ataupun powerpoint, oleh sebab itu ada beberapa aplikasi pengolah kata yang dibutuhkan, antara lain OpenOffice, KingOffice atau lainnya dimana dalam aplikasi tersebut terdapat aplikasi pengolah kata, lembar kerja, ataupun presentasi. Selain itu ada aplikasi tertentu yang dibutuhkan sesuai dengan jurusan masing-masing.

\section{Video Conference}

Sebagai pengajar, sering menggunakan pengolah kata untuk menampilkan document, atau materi pembelajaran dalam bentuk powerpoint. Oleh sebab itu dalam video conference membutuhkan aplikasi pengolah kata antara lain OpenOffice, KingOffice atau lainnya. Selain itu perlu aplikasi flash untuk menjalankan video dan audio. Secara umum kebutuhan aplikasi, dibagi menjadi dua yaitu aplikasi umum dan aplikasi khusus. Aplikasi umum yang digunakan untuk mengakses Learning Managemen System adalah browser. Sedangkan aplikasi khusus dibutuhkan yaitu file explorer, document (office), screen capturer, dan flash adalah aplikasi yang dibutuhkan dalam perkuliahan online learning

\section{Kebutuhan Perangkat Keras}

Penggunaan sistem komputer sebagai alat bantu dalam menyelesaikan tugas-tugas atau pekerjaan sudah bukan menjadi hal yang aneh, tapi merupakan suatu keharusan karena banyak kemudahan-kemudahan yang bisa diperoleh. Komputer terdiri perangkat keras dan perangkat lunak. Perangkat lunak memberikan instruksi-instruksi kepada perangkat keras untuk melakukan suatu tugas tertentu. Kebutuhan perangkat keras dibagi menjadi: input device, processing device, dan output device.

Input device dalam perkuliahan Binus Online Learning adalah perangkat-perangkat sebagai peng-input data yang akan diolah dalam komputer, seperti mengerjakan tugas, mahasiswa harus menggunakan keyboard, menjawab forum diskusi, bertanya di video conference, kamera webcam digunakan sebagai alat untuk mengambil video peserta saat melaksanakan video conference, audio juga digunakan untuk mengambil suara dari peserta, selain itu dibutuhkan juga screen capturer yang digunakan untuk mengambil gambar dari internet.

Processing device yang digunakan adalah Central Processing Unit (CPU), untuk mengolah aplikasi maupun sistem operasi pada tablet. Kebutuhan CPU minimal adalah Core 2, dengan speed 1.2 Ghz. Dalam CPU dibutuhkan: (a) Storage dengan ukuran sebesar 32 GB. (b) RAM dengan ukuran sebesar 2 GB. (c) Kamera dengan ukuran sebesar 5MP di depan. (d) Jaringan nirkabel Wifi IEEE $802.11 \mathrm{~b} / \mathrm{g} / \mathrm{n}$. (e) bluetooth 4.0 
Output device yang digunakan adalah Monitor/layar multi sentuh dengan kapasitif 7”, USB drive. Untuk membuat kebutuhan perangkat keras, perlu diberikan informasi mengenai fungsi yang menunjang kegiatan yang dilaksanakan. Adapun beberapa fungsi mengetik menggunakan keyboard, monitor untuk melihat apa yang diketik dan fungsi USB untuk menyimpan tugas. Oleh sebab di atas, maka perangkat keras yang dibutuhkan dapat dilihat pada tabel di bawah ini :

Tabel 2 Kebutuhan Perangkat Keras untuk Perkuliahan Online

\begin{tabular}{|c|c|c|}
\hline Kegiatan & $\begin{array}{l}\text { Kebutuhan } \\
\text { Perangkat Keras }\end{array}$ & Fungsi \\
\hline Forum Diskusi & $\begin{array}{l}\text { Keyboard, } \\
\text { (o) Monitor, } \\
\text { (o) USB drive, } \\
\text { (p)Wifi, }\end{array}$ & $\begin{array}{l}\text { Menjawab pertanyaan di forum diskusi dengan } \\
\text { cara mengetik, } \\
\text { Melihat yang diketik, } \\
\text { Menyimpan dan mengunduh dari penyimpanan } \\
\text { eksternal USB memory } \\
\text { Koneksi jaringan }\end{array}$ \\
\hline $\begin{array}{l}\text { Pengerjaan Tugas Personal dan Tugas } \\
\text { Kelompok }\end{array}$ & $\begin{array}{l}\text { Keyboard, } \\
\text { (o) Monitor, } \\
\text { (o) USB drive, } \\
\text { (p) Wifi, } \\
\text { (p) Bluetooth }\end{array}$ & $\begin{array}{l}\text { Menjawab tugas dengan cara mengetik, } \\
\text { Melihat yang file yang dikirim, } \\
\text { Menyimpan dan mengunduh dari penyimpanan } \\
\text { eksternal USB memory } \\
\text { Koneksi jaringan, } \\
\text { Memindahkan materi dari PC ke tablet }\end{array}$ \\
\hline Video Conference & $\begin{array}{l}\text { WebCam (Front Camera), } \\
\text { (i/o) Audio, } \\
\text { (i)Keyboard, } \\
\text { (o)Monitor, } \\
\text { (p)Wifi }\end{array}$ & $\begin{array}{l}\text { Menampilkan video peserta sebagai presenter, } \\
\text { Menampilkan suara presenter, atau peserta } \\
\text { bertanya } \\
\text { Memberikan pertanyaan tertulis, } \\
\text { Melihat instruktur dan materi, } \\
\text { Koneksi jaringan }\end{array}$ \\
\hline $\begin{array}{c}\text { Legend: i - input device } \\
\text { p - processing device } \\
\text { o - output device }\end{array}$ & & \\
\hline
\end{tabular}

Kebutuhan perangkat keras dibagi menjadi input device yaitu keyboard, audio dan webcam, sedangkan processing device dibutuhkan yaitu Wifi dan bluetooth, serta output device yaitu monitor, USB drive, dan audio.

\section{SIMPULAN}

Berdasarkan pembahasan yang telah diuraikan pada bab-bab sebelumnya, maka dapat diambil kesimpulan sebagai berikut: (1) Saat ini blackberry banyak digunakan, tetapi Sistem operasi handphone/tablet yang dianggap akan berkembang pesat dan banyak digunakan adalah sistem operasi android. (2) Mayoritas responden menggunakan pengolah kata, sebanyak 64 orang atau 89\%, sedangkan lembar kerja dan pengolah gambar sebanyak 3 orang atau 4\%, multimedia, animasi sebanyak 1 orang atau 2\%, sedangkan lain-lain sebanyak 1 orang atau 1\%. 3. (3) Kebutuhan aplikasi, dibagi menjadi dua yaitu aplikasi umum dan aplikasi khusus. Aplikasi umum yang digunakan untuk mengakses Learning Managemen System adalah browser. Sedangkan aplikasi khusus dibutuhkan yaitu file explorer, document (office), screen capturer dan flash adalah aplikasi yang dibutuhkan dalam perkuliahan online learning. (4) Kebutuhan perangkat keras dibagi menjadi input device yaitu keyboard, audio dan webcam, sedangkan processing device yang dibutuhkan yaitu Wifi, dan bluetooth, serta output device yaitu monitor, USB drive, dan audio. 


\section{DAFTAR PUSTAKA}

Andy, Y. (2007). Perancangan dan Implementasi Mobile Learning untuk Pembelajaran Bahasa Jepang Berbasis Brew. Bandung: STEI ITB.

Cause, Leslie, J., Chen, Dora, W. (2010). A Tablet Computer for Young Children? Exploring Its Viability for Early Childhood Education, 43(1), 75-98, diakses 17 Desember 2012 dari http://search.proquest.com/docview/750120203/13B0D2CB7911A1174E2/45?accountid=31 532.

Effendi, Empy, Hartono, Zhuang. (2005). E-learning: Konsep dan Aplikasi. Ed. 1. Yogyakarta : CV Andi Offset.

Morris, Michael, S., Stommel, Jesse. (2013). The Discussion Forum is Dead; Long Live the Discussion Forum. Hybrid Pedagogy, diakses 12 Nopember 2013 dari http://www.hybridpedagogy.com/Journal/files/Discussion_Forum_is_Dead.html

Microsoft. (2000). COMDEX/Fall 2000: Gates Tells Capacity Crowd That New Model of Software-toSoftware Interaction Will Shape Future of Internet Computing, diakses 14 Desember 2012 dari http://www.microsoft.com/en-us/news/features/2000/nov00/11-13comdex.aspx

Pearson Foundation. (2011). Survey on Students and Tablets, diakses 17 Desember 2012 dari http://www.pearsonfoundation.org/downloads/PF_Tablet_Survey_Summary.pdf

Rachel, Roberts. (2009). Video Conferencing in Distance Learning: A New Zealand Schools' Perspective. Journal of Distance Learning, 2009(1), 91 -107, diakses 20 November 2013.

Republika. (2012). Smartphone dan Tablet Makin Marak, PC Makin Terpinggirkan?, diakses 17 Des 2012 dari http://www.republika.co.id/berita/trendtek/gadget/12/12/12/mevnj4-smartphonedan-tablet-makin-marak-pc-makin-terpinggirkan

Ruth, Stephen. Is E-Learning Really Working? The Trillion-Dollar Question. IEEE Internet Computing [Online], 14(2), 78-82, diakses 27 Juni 2012 dari http://proquest.umi.com/pqdweb?index=25\&did=1977595321\&SrchMode=1\&sid=1\&Fmt= 2\&VInst=PROD\&VType=PQD\&RQT=309\&VName=PQD\&TS=1290947966\&clientId=68 84.

Tsai, August. (2010). An Integrated e-Learning Solution in Hospitals. Journal of Global Business Issues [Online]. 4(2), 85-93, diakses 27 Juni 2012 dari http://proquest.umi.com/pqdweb?index $=8 \&$ did=2198231821\&SrchMode $=1 \&$ sid $=1 \&$ Fmt $=2$ \&VInst=PROD\&VType=PQD\&RQT=309\&VName=PQD\&TS=1290947651\&clientId=688 14

Watkins, R. (2006). In 75 E-Learning Activities (Making Online Learning Interactive).San Francisco: Pfeiffer. 